\title{
OFFIGIAL COMMUNICATIONS
}

Meetings of the Society have been fixed at the following times and places:

The Summer Meeting of the Society, at Vassar College, September 6-8, 1923 .

Abstracts must be in the hands of the Secretary of the Society not later than August 8.

The San Francisco Section, in Los Angeles, September I7-20, I 923 .

Abstracts must be in the hands of the acting Secretary of the Section, D. N. Lehmer, not later than July 26.

\section{New York City, October 27, 1923.}

Abstracts must be in the hands of the Secretary of the Society not later than October I3.

The Southwestern Section, in Columbia, Missouri, December I, I923.

Abstracts must be in the hands of the Secretary of the Section, E. B. Stouffer, not later than November I6.

The Annual Meeting of the Society, in New York City,

December 27-28, 1923. See also this Bulletin, vol. 29, No. 4 (April, I923), p. 188.

Abstracts must be in the hands of the Secretary of the Society not later than November 29.

The Twentieth Western Meeting of the Society (Fiftysecond Meeting of the Chicago Section), in Cincinnati, December 28-29, 1923. See also this Bulletin, vol. 29, No. 5 (May, 1923), p. I97.

Abstracts must be in the hands of the Secretary of the Chicago Section, Arnold Dresden, 2II4 Vilas St., Madison, Wis., not later than November 29.

R. G. D. RichaRdson, Secretary of the Society.

\section{COLLECTED WORKS OF LEONARD EULER}

Libraries or individuals wishing for information with a view to joining in promoting this great international undertaking, should communicate with the Official Representative of the Euler Committee for the United States and Canada,

R. C. Archibald, Brown University, Providence, R. I. 


\section{Whole Number 316}

\section{CONTENTS}

Report on Continuous Curves from the Viewpoint of Analysis

Situs. By R. L. Moore

A Generalization of a Property of an Acnodal Cubic Curve. By Harold Hilton

On Uniform Limitedness of Sets of Functional Operations. By T. H. Hildebrandt.

Beck on Coordinate Geometry. By J. L. Coolidge.

Keynes on Probability. By E. B. Wilson................................... 319

Blaschke on Differential Geometry. By G. A. BuIss................ 322

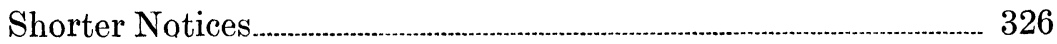

Notes ....

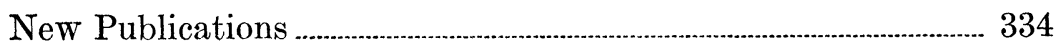

Any communication intended for this BuLLetin may be addressed to the American Mathematical Society, Prince and Lemon Streets, Lancaster, Pa., or may be sent to separate officials of the Society as follows:

Articles for insertion in the Bulletin should be addressed to E. R. Hedrick, Editor of the Bulletin, 304 Hicks Ave., Columbia, Mo. Reviews should be sent to J. W. Young, Dartmouth College, Hanover, N. H. Notes should be sënt to R. W. Burgess, Brown University, Providence, R. I.

Subscriptions to the Bulletin, orders for back numbers, and inquiries in regard to non-delivery of current numbers should be addressed to The American Mathematical Society, 501 West 116th Street, New York.

Advertising space is available in the Bullemin at $\$ 16$ per page, $\$ 9$ per halfpage, $\$ 5$ per quarter page, per issue. Address correspondence regarding advertising to H. L. Riwer, University of Iowa, Iowa City, Iowa.

Changes of address of members, exchanges, and subscribers should be communicated at once to the Secretary of the Society, R. G. D. Richardson, 501 West 116th Street, New York.

The initiation fees $(\$ 5.00)$ and annual dues $(\$ 6.00)$ of members of the Society are payable to the Treasurer of the Society, W. B. Fine, 501 West 116th Street, New York.

Lancaster Press, Inc., Lancaster, Pa. 